\title{
CHARACTERIZATION OF PESTICIDE CONSUMPTION IN THE COUNTY OF SANTARÉM, PARÁ, BRAZIL
}

\author{
Nicolas SOUMIS*, Mare ROULET*, Marc LUCOTTE*
}

\begin{abstract}
Many potentially harmful pesticides for both human health and the environment are used in Brazilian Amazon. However, no scientific datum on pesticide usage is presently available for this region. Consequently, it is difficult to assess which substances are used and in which quantities. As an important premise for future work on pesticide contamination in the county of Santarém (State of Pará, Brazil), a survey was conducted in order to qualify and quantify the use of some pesticides in this region. This investigation was made between January and March 1997 and August and October 1998 and revealed use of several organophosphates, synthetic pyrethroids and carbamates insecticides. Furthermore, many herbicides and fungicides were listed. These pesticides are used for agriculture, domestic, and sanitary programs. This paper also provides a first estimation of quantities of some insecticides commonly used in agriculture (chlorpyrifos, malathion, metamidophos and methyl-parathion). The annual consumption for these four compounds is estimated at ca. $1910 \mathrm{~kg}$. Organophosphate insecticide consumption in the county of Santarem seems to be lower than the Brazilian average in terms of «per capita» and "per agricultural area» consumptions. Nevertheless, this county uses toxic substances on sensitive environments such as floodplains (várzeas), making relevant a thorough study on the potential contamination of this environment and its biota.
\end{abstract}

Key-words : Amazon, pesticides, consumption, utilization.

Caracterização do consumo de pesticidas no município de Santarém, Amazônia brasileira

RESUMO - Muitos pesticidas potencialmente nocivos para a saúde humana e meio ambiente são usados na Amazônia brasileira. Apesar desse fato, nenhum dado científico sobre sua utilização está disponivel para esta região. Por isto, torna-se extremamente dificil uma avaliação qualitativa e quantitativa dos produtos usados. Desta forma, como uma premissa importante para futuros trabalhos visando a contaminação por pesticidas, um levantamento sobre o comércio e o uso desses agroquimicos foi realizado no Município de Santarém, Pará, Brasil. A pesquisa, feita entre janeiro e março de 1997 e entre agosto e outubro de 1998, revelou o uso de vários inseticidas pertencentes aos grupos organofosforados, piretróides sintéticos e carbamatos. Além disso, foram achados muitos herbicidas e fungicidas. Observou-se que esses pesticidas são empregados na agricultura, em programas sanitários e uso doméstico. Cálculos das quantidades de alguns inseticidas importantes usados na agricultura (clorpirifós, malathion, metamidophos, parathion metil) indicam um consumo anual de $1910 \mathrm{~kg}$ para estes quatro produtos. Os consumos «per capita» e «por superfície agrícola» de inseticidas organofosforados em Santarém são inferiores às médias brasileiras. No entanto, visto que este municipio usa substâncias tóxicas em ambientes sensiveis, como várzeas, seria apropriado efetuar estudos sobre a contaminação potencial do ambiente e da biota nesta região.

Palavras-chave: Amazônia, pesticidas, consumo, utilização.

\section{INTRODUCTION}

Forestry, agriculture and mining are among the economic activities commonly practiced in the Brazilian
Amazon (Fearnside, 1987; Hall, 1989). They often require huge quantities of pesticides that are potentially harmful to both human health and the environment. Furthermore, insecti-

\footnotetext{
* Chaire de recherche en environnement Hydro-Québec/CRSNG/UQAM, Université du Québec à Montréal, C. P. 8 888, Succ. Centre-Ville, Montréal, Québec, Canada, H3C 3P8.
} 
cides are also been used to control vector-borne diseases. Present tools allowing the characterization of pesticide use in the Brazilian Amazon are still very limited. FAO (Food and Agriculture Organization) estimated that Brazil used about 14538 metric tons $(\mathrm{t})$ of insecticides, $25017 \mathrm{t}$ of herbicides, and $4719 \mathrm{t}$ of fungicides in $1995^{1}$. However, national averages registered by FAO are estimated to Brazil as an homogeneous whole and do not give any idea of the gap between the North and the South of this country. Otherwise, Brazilian organizations which are related to agriculture or to the environment do not register any data on pesticides. IBGE (Instituto Brasileiro de Geografia e Estatistica) produces a yearly detailed agricultural inventory of the country but nothing is mentionned about pesticides. Neither IBAMA (Instituto Brasileiro do Meio Ambiente e dos Recursos Naturais Renováveis) nor EMBRAPA (Empresa Brasileira de Pesquisa Agropecuária), respectively the federal environmental agency and the federal Brazilian research company in agriculture, compile this kind of information. Finally, despite the Brazilian bill $N^{\circ} 7802$ of the $11^{\text {th }}$ of July 1989 claiming that all agricultural pesticide sales must be registered (DDIV, 1998), it is still impossible to find this type of inventory for the region covered by this study.

Due to lack of official data on pesticide use, an investigation was performed in Santarém (State of Pará, Brazil) in order to qualify and quantify the utilization of several pesticides in this county of the Brazilian Ama- zon. This investigation is the first part of a research program aiming to evaluate the potential contamination of the local environment by these substances. Emphasis has been put on agriculture, since it is a very important activity for the county. The information contained in this paper will be particularly useful for future work looking at the pesticide issue in this territory, and for the assessment of both environmental and health risks.

\section{METHODOLOGY}

The county of Santarém $\left(2^{\circ} 25^{\prime} \mathrm{S}\right.$, $54^{\circ} 43^{\prime} \mathrm{W}$ ) is the third most important urban center of the Brazilian Amazon, after Manaus (Amazonas) and Belém (Pará). Located at the confluence of the Tapajós and the Amazon rivers in the State of Pará, Santarem is situated in the micro-region of Santarem, meso-region of Lower-Amazon, in the Western region of Pará (Fig. 1). Its territory covers about $24422 \mathrm{~km}^{2}$. Of this area, between $1055 \mathrm{~km}^{2}$ and 1 $847 \mathrm{~km}^{2}$ are occupied by agriculture (IBGE, 1997a), which represent between $4,3 \%$ and $7,6 \%$ of all the county area. According to the 1996 census, the population of Santarem is about 242165 inhabitants (IBGE, 1997b), of which $69,4 \%$ live in urban areas and $30,6 \%$ in rural areas (SEMAB, 1997).

The local economy is mainly based on fishing, forestry and agriculture (Scatena et al., 1996; SEMAB, 1997). The city of Santarém has twelve specialized stores which supply pesticides to the region, mainly for

\footnotetext{
1. These figures are drawn from FAOSTAT, a FAO's database available on the Web. To consult them online, go to http://apps.fao.org/page/collections, then choose the data collection "Pesticides consumption" under the domain "Means of production".
} 
agriculture and gold mining.

Information compiled in this study was collected by survey. The qualitative part of the study was conducted between January and March 1997 and between August and October 1998. Oral reports were gathered from farmers, growers, agricultural and sanitary technicians, agricultural products salesmen, and persons in charge of technical assistance organizations which have been coupled with observations made in several places where pesticides are likely to be used or sold. This information enabled us to assess which were the most commonly found pesticides in Santarém, in terms of available brands or formulations.

The quantitative part of the investigation was made between August and October 1998. Among the twelve known stores selling pesticides in Santarém, four were chosen. Representative stores of the local agricultural context were selected according to the destination (dry land and floodplain) and the volume (low and high) of sales. In each of them, an inquiry was conducted to know which products were sold and in what quantity. In order to validate this estimation, we made sure that pesticides sold by sampled stores were staying in the boundaries of the municipality of Santarem, and that there was no other significant source of pesticides for this territory. Various brands or formulations sales have been converted into quantities of active ingredients, then grouped according to their chemical nature. To estimate quantities of pesticides used in the whole municipality, average quantities obtained for active ingredients were extrapolated to all stores of the city using this formula:

Quantities used in Santarém $=$ $\Sigma$ (sales of sampled stores) - total of stores known in Santarém (12) divided by the number of stores sampled during the investigation (4)

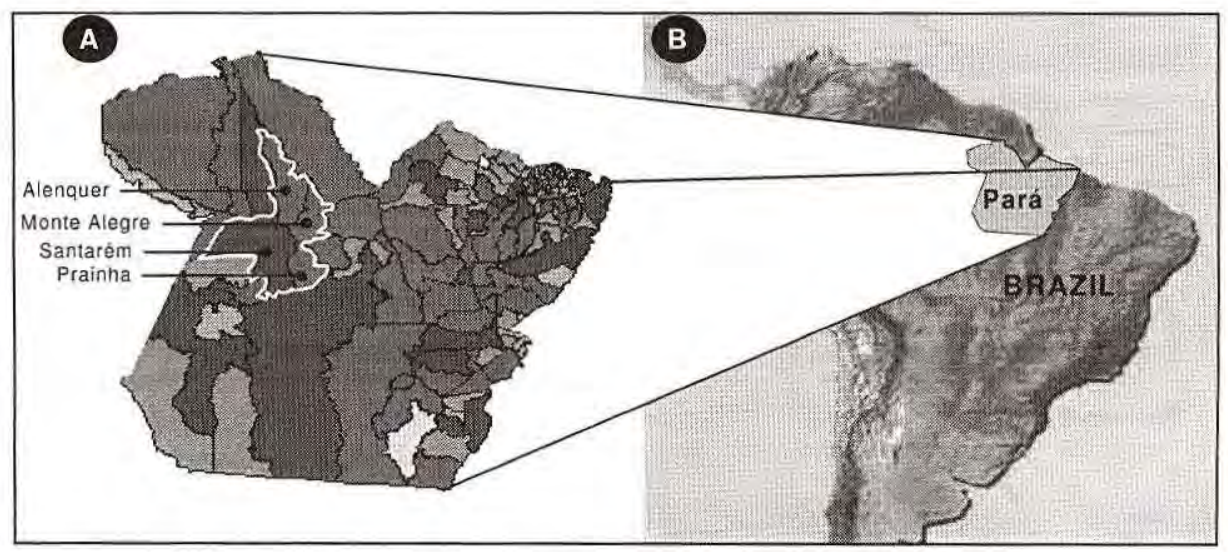

Figure 1. A) Localization of the county of Santarem on the map of the State of Pará, Brazil. The micro-region of Santarem is outlined in white. B) Localization of State of Para on the South America's map. 
Total quantities of pesticides used in Santarém (in active ingredients equivalents) were then divided per the total area of the municipality, per the agricultural area (total and under use), and "per capita" . The agricultural area in use includes permanent and temporary crops, as well as natural and manmade pastures. The total agricultural area includes, in addition to the zones mentionned above, unused productive soils and those left in fallow.

\section{RESULTS}

It was possible to define three main domains where pesticides are used: agriculture (on dry land and floodplain), eradication programs of sanitary organizations, and domestic utilization. Tables included in this section do not constitute an exhaustive inventary of pesticides found in Santarém. They rather indicate products currently used in this county.

\section{a) Domestic utilization of pesticides}

The domestic utilization principally aims at the eradication, control, or eviction of insects living in houses. Therefore, products found are exclusively short half-life insecticides (Ray, 1991) freely available in many stores. The list in (Tab. 1) was made from an investigation of eleven of such stores. The domestic market is obviously dominated by synthetic pyrethroids which are, despite their low persistence, efficent insecticides (Ray, 1991). Besides, this family is often used for that purpose elsewhere in the world (Ecobichon, 1991).

\section{b) Sanitary utilization of pesticides}

"Fundação Nacional de Saúde" (FNS) is the organization responsible for sanitary pulverization programs in the county of Santarém. A meeting with an official of FNS allowed us to

Table 1. Principal domestic insecticides found in groceries and convenience stores in the city of Santarém, State of Pará, Brazil.

\begin{tabular}{|c|c|c|c|}
\hline commercial name & active ingredients (common names) & CAS number & chemical class \\
\hline Baygon® & $\begin{array}{l}\text { propoxur } \\
\text { dichlorvos }\end{array}$ & $\begin{array}{l}114-26-1 \\
62-73-7\end{array}$ & $\begin{array}{l}\text { carbamate } \\
\text { organophos phate }\end{array}$ \\
\hline Detefon ${ }^{\circ}$ & $\begin{array}{l}\text { dichlorvos } \\
\text { tetramethrin }\end{array}$ & $\begin{array}{l}62-73-7 \\
7696-12-0\end{array}$ & $\begin{array}{l}\text { organophosphate } \\
\text { synthetic pyrethroid }\end{array}$ \\
\hline Rodasol® & $\begin{array}{l}\text { d-allethrin } \\
\text { phenothrin }\end{array}$ & $\begin{array}{l}42534-61-2 \\
26002-80-2\end{array}$ & $\begin{array}{l}\text { synthetic pyrethroid } \\
\text { synthetic pyrethroid }\end{array}$ \\
\hline Rodox@ & $\begin{array}{l}\text { cypermethrin } \\
\text { tetramethrin }\end{array}$ & $\begin{array}{l}52315-07-8 \\
7696-12-0\end{array}$ & $\begin{array}{l}\text { synthetic pyrethroid } \\
\text { synthetic pyrethroid }\end{array}$ \\
\hline$S B P \circledast$ & $\begin{array}{l}\text { d-allethrin } \\
\text { d-tetramethrin } \\
\text { cyphenothrin }\end{array}$ & $\begin{array}{l}42534-61-2 \\
7696-12-0 \\
39515-40-7\end{array}$ & $\begin{array}{l}\text { synthetic pyrethroid } \\
\text { synthetic pyrethroid } \\
\text { synthetic pyrethroid }\end{array}$ \\
\hline
\end{tabular}


characterize the sanitary utilization of pesticides (Tab. 2). Pulverization programs aim mainly at the diminution of tropical human diseases incidence such as malaria, dengue and leischmaniosis by controling mosquito populations (Anopheles spp., Aedes spp., Culex spp. respectively).

Officially, FNS no longer uses DDT since May 1996. Also kadethrin is no longer used because it caused skin burns to technicians who handled it. Etophenprox is the only insecticide still used by FNS. This synthetic pyrethroid seems to be very efficent (Jena et al., 1992; Diraviam \& Viraktamath, 1993), weakly toxic to mammals (Krishnaiah \& Kalode, 1993), and poorly persistent in the environment. However, some authors have reported certain harmful effects of this insecticide on the aquatic biota (Baktharatchagan \& David, 1991; Shakoori et al., 1992).

\section{c) Agricultural utilization of pesticides}

Contrary to domestic or sanitary utilization of pesticides, a wider range of products is used in agriculture to control not only insects, but also other pests like weeds and fungi. Thus, besides insecticides, it is possible to note an agricultural use of many herbicides and fungicides. In order to investigate the different aspects of the Amazonian agriculture, various places were visited. Table 3 depicts the array of pesticides that may be found in agricultural stores of Santarem. For the needs of this study, seven such stores were visited. Attention was paid to the most currently used or sold products. Despite the fact that most of pesticide families are present, organophosphate insecticides $(43 \%)$ clearly dominate the market in terms of available brands or formulations. Then follow fungicides $(21 \%)$ and herbicides $(14 \%)$, all chemical families together.

Agricultural activities are practiced on distinct environments, namely the dry land (terra firme) and floodplains (várzeas). This distinction is important since products used are slightly different from one environment to the other. Traditionally, agriculture is practiced on the dry land of the Amazonian plateau, so called because they stay free of water all year. In the county of Santarem, the dry land

Table 2. Insecticides used during 1997-98 in sanitary programs of the "Fundação Nacional de Saúde" in the city of Santarém, State of Pará, Brazil.

\begin{tabular}{lllll}
\hline commercial name & active ingredients & CAS number & chemical class & use \\
\hline$?$ & DDT & $50-29-3$ (P.P' DDT) & organochlorine & prior \\
$?$ & kadethrin & $58769-20-3$ & synthetic pyrethroid & prior \\
Vectron ${ }^{8}$ & ethofenprox & $80844-07-1$ & synthetic pyrethroid present \\
\hline
\end{tabular}


Table 3. Principal pesticides found in agricultural stores of Santarém, State of Pará, Brazil.

\begin{tabular}{|c|c|c|c|}
\hline commercial name & active ingredients (common names) & CAS number & chemical clss* \\
\hline Agrinose $\circledast$ & copper oxychloride & $1332-65-6$ & inorganic salt (F) \\
\hline Agrivin@† & carbaryl & $63-25-2$ & carbamate (I) \\
\hline Agrophos ${ }^{8}$ & monocrotophos & $6923-22-4$ & organophosphate (I) \\
\hline Benlate $500 \circledast$ & benomyl & $17804-35-2$ & nitrogen heterocycle (F) \\
\hline Cobre Sandoz® & copper oxychloride & $1332-65-6$ & inorganic salt (F) \\
\hline Cuprogarb $350 \circledast / 500 \circledast$ & copper oxychloride & $1332-65-6$ & inorganic salt (F) \\
\hline Diazinon $60 \mathrm{CE} \otimes, 400$ PM $₫$ & diazinon & $333-41-5$ & organophosphate (I) \\
\hline Decis 25 CE® & deltamethrin & $52918-63-5$ & synthetic pyrethroid (I) \\
\hline Dipterex $500 \circledast$ & trichlorfon & $52-68-6$ & organophosphate $(\mathrm{I}, \mathrm{V})$ \\
\hline Dithane PM® & mancozeb & $8018-01-7$ & dithiocarbamate (F) \\
\hline DMA 806 BR@ & 2, 4-D & $94-75-7$ & chlorophenoxy $(\mathrm{H})$ \\
\hline Folidol $600 \AA$ & methyl-parathion & $298-00-0$ & organophosphate (I) \\
\hline Folisuper $600 \mathrm{BR} @$ & methyl-parathion & $298-00-0$ & organophosphate (I) \\
\hline Folpan Agricur 500PM & folpet & $133-07-3$ & chloroalkyl (F) \\
\hline Formicidol Pó® & chlorpyrifos & $2921-88-2$ & organophosphate (I) \\
\hline Funguran Azul@ & copper oxychloride & $1332-65-6$ & inorganic salt $(F)$ \\
\hline Garion 480 BR 8 & triclopyr & $55335-06-3$ & pyridine $(H)$ \\
\hline Glifosato $480 \circledast$ & glyphosate & $1071-83-6$ & organophosphate $(\mathrm{H})$ \\
\hline Gramoxone® & paraquat dichloride & $1910-42-5$ & bipyridinium $(\mathrm{H})$ \\
\hline $\operatorname{Jima}(8$ & chlorpyrifos & $2921 \cdot 88-2$ & organophosphate (I) \\
\hline Karate 50 CE@ & $\lambda$-cyalothrin & $91465-08-6$ & synthetic pyrethroid (I) \\
\hline K-Othrine ${ }^{8}$ & deltamethrin & $52918-63-5$ & synthetic pyrethroid (I) \\
\hline Lorsban 480 BR@ & chlorpyrifos & $2921-88-2$ & organophosphate (1) \\
\hline Madaldrin 400 PM 8 & diazinon & $333-41-5$ & organophosphate (I) \\
\hline Malathion 500 CE@ & malathion & $121-75-5$ & organophosphate (I) \\
\hline Malathion Pó@ & carbaryl & $63-25-2$ & carbamate (I) \\
\hline Mirex S® & sulfluramide & $4151-50-2$ & organofluorine (I) \\
\hline Nitrosinß & chlorpyrifos & $2921-88-2$ & organophosphate (I) \\
\hline Pikapau@ & sulfluramide & $4151-50-2$ & organofluorine (I) \\
\hline Pikthrine® & cypermethrin & $52315-07-8$ & synthetic pyrethroid (I) \\
\hline Stron® & metamidophos & $10265-92-6$ & organophosphate $(A, I)$ \\
\hline Tamaron BR@ & metamidophos & $10265-92-6$ & organophosphate $(A, 1)$ \\
\hline Termicidol® & endosulfan & $115-29-7$ & organochlorine (I) \\
\hline Tordon RTU®/2,4-D® & $\begin{array}{l}2,4-D \\
\text { picloram }\end{array}$ & $\begin{array}{l}72-43-5 \\
1918-02-1\end{array}$ & $\begin{array}{l}\text { chlorophenoxy }(\mathrm{H}) \\
\text { heterocyclic }(\mathrm{H})\end{array}$ \\
\hline
\end{tabular}

* : $A=$ acaricide $F=$ fungicide $H=$ herbicide $I=$ insecticide $V=$ vermicide

$\dagger$ : This product seems to be withdrawn from market later than the investigation. 
is characterized by beef cattle ranching and crops of acerola, banana, citrus, cocoa, coconut, coffee, cupuaçu, mango, pineapple and urucú (Scatena et al., 1996; SEMAB, 1997). These lands are concentrated in the region of Planalto (SEMAB, 1997). Information collected from three stores which only sell pesticides to dry land farms and from CEPLAC (Comissão Executiva do Plano da Lavoura Cacaueira), an agricultural technical assistance organization, were useful to list some of the pesticides used on terra firme (Tab. 4). According to data compiled in Table 4, pesticides used on dry land are mainly fungicides $(33 \%)$, organophosphate insecticides $(22 \%)$, and herbicides $(22 \%)$, with respect to the number of brands or formulations found.

Besides the dry land, agriculture is also practiced on floodplains (várzeas) along the Amazon river. Várzeas cover about $2 \%$ of the Amazon basin (Fearnside, 1990). These soils, despite their flooding during several months every year, present an attractive feature for agriculture: they benefit from a natural enrichment

Table 4. Some pesticides used in agriculture on dry land in the county of Santarem (State of Pará, Brazil), according to agricultural stores and technical assistance agencies.

\begin{tabular}{|c|c|c|c|}
\hline commercial name & a ctive ingredients (common names) & CAS number & chemical class* \\
\hline Agrivineit $t$ & carbaryl & $63-25 \cdot 2$ & carb amate (I) \\
\hline Benlate $500 \circledast$ & benomyl & $17804-35-2$ & nitrogen hetero cycle (F) \\
\hline Cobre S andoz $\circledast$ & copper oxychloride & $1332-65-6$ & inorganic salt $(F)$ \\
\hline Cuprogarb $350 \circledast / 500 \circledast$ & copper oxychloride & $1332-65-6$ & inorganic salt ( $F$ ) \\
\hline Decis 25 CE® & deltamethr in & 52918.63 .5 & synthetic pyrethroid (I) \\
\hline Diazinon 400 PM® & diazinon & $333-41-5$ & organophosphate (1) \\
\hline Dipterex $500 \circledast$ & trichlorfon & $52-68-6$ & organophosphate (I, V) \\
\hline Dithane $P M \otimes$ & mancozeb & $8018-01-7$ & dithioca rbamate (F) \\
\hline DMA 806 BR@ & $2,4-D$ & $94-75-7$ & chlorophenoxy (H) \\
\hline Folidol $600 \circledast$ & methyl-parathion & $298-00-0$ & organophosphate (I) \\
\hline Formicidol Pó@ & chlorpyrifos & $2921-88-2$ & organophosphate (I) \\
\hline Funguran Azul@ & copper oxychloride & $1332-65-6$ & inorganic salt (F) \\
\hline Gramoxone® & paraquat dichloride & $1910-42-5$ & bipyridinium $(\mathrm{H})$ \\
\hline Mala thion Pó@ & carbaryl & $63-25-2$ & carbamate (I) \\
\hline Mancozeb M $45 \circledast$ & mancozeb & $8018-01-7$ & dithioca rbamate (F) \\
\hline Mirex@ & sulflura mide & $4151-50-2$ & organofluorine (I) \\
\hline Roundup@ & glyphosate & $1071-83 \cdot 6$ & organophosphate $(\mathrm{H})$ \\
\hline Tama ron $B R B$ & metamidophos & $10265-92-6$ & organophosphate $(A, I)$ \\
\hline Tordon 2, 4-D® & $\begin{array}{l}\text { 2,4-D } \\
\text { picloram }\end{array}$ & $\begin{array}{l}72-43-5 \\
1918-02-1\end{array}$ & $\begin{array}{l}\text { chlorophenoxy }(\mathrm{H}) \\
\text { heterocyclic }(\mathrm{H})\end{array}$ \\
\hline
\end{tabular}

$\because \mathrm{F}=$ fungicide $\mathrm{H}=$ herbicide $\mathrm{I}=$ insecticide

$\dagger$ : This product seems to be withdrawn from market later than the investigation. 
coming from the nutrients left by flood sediments (Furch, 1997). Thus, várzeas normally do not require addition of fertilizers as the dry land does. Faced with poor results arising from the dry land exploitation during the seventies, várzeas began to be more considered in the eighties for regional agricultural development (de Mérona, 1993). The region of Santarém is one of those with the greatest concentration of varzeas of all the Amazon. Commercial and food crops, as well as ranching (water buffalo, Bubalus bubalis and indian buffalo, Bos indicus), are found on these floodplains.

In a general way, várzeas surrounding Santarém are occupied by small producers who own or rent small areas of land where food crops are grown (McGrath et al., 1993; Etchart, 1997), such as banana, cabbage, cucurbits, manioc, green onion, hot pepper, mild pepper and tomato.
Surplus crops are sold in Santarem markets, which allows a modest income for «varzeiros». Pesticide applications are manually made, often with a portable sprayer. Pulverizations are made every 5 to 20 days. The frequency varies from one crop to another, from one pesticide to another and, to a certain extent, according to the judgment of producers. Visits to ten small crop producers located on floodplains along the Amazon river were made to assess the kind of pesticides used on várzeas (Tab. 5). Products found are mainly organophosphate insecticides $(50 \%)$ and fungicides $(33 \%)$. Far behind, herbicides $(8 \%)$ complete the list.

Várzeas occupied by small producers present a consistent whole. Indeed, crops, agricultural practices as well as pesticides used are about the same on small holders várzea areas. However, there is a difference with várzeas where ranching is practiced.

Table 5. Principal pesticides found in small crops in várzeas near Santarém, State of Pará, Brazil.

\begin{tabular}{|c|c|c|c|}
\hline commercial name & active ingredients (common names) & CAS number & chemical clas s* \\
\hline Agrinose $\Theta$ & copper oxychloride & $1332-65-6$ & inorganic salt $(F)$ \\
\hline Benlate $500 \circledast$ & benomyl & $17804-35-2$ & nitrogen heterocycle (F) \\
\hline Decis $\circledast$ & deltamethrin & $52918-63-5$ & synthetic pyrethroid (I) \\
\hline Diazinon $400 \mathrm{PM} \otimes$ & diazinon & $333-41-5$ & organ ophosphate (I) \\
\hline Dithane PM® & mancozeb & $8018-01-7$ & dithioc arbamate (F) \\
\hline Folidol@ & methyl-parathion & $298-00-0$ & organophosphate (I) \\
\hline Folisuper® & methyl-parathion & $298-00-0$ & organophosphate (I) \\
\hline Funguran Azul® & copper oxychloride & $1332-65-6$ & inorganic salt (F) \\
\hline Malathion $500 \mathrm{CE} \circledast$ & malathion & $121-75-5$ & organophosphate (1) \\
\hline Nitrosin $(8$ & chlorpyrifos & $2921-88-2$ & organophosphate (I) \\
\hline Roundup ${ }^{\circledR}$ & glyphosate & $1071-83-6$ & organophosphate $(\mathrm{H})$ \\
\hline Tamaron $\circledast$ & metamidophos & $10265-92-6$ & organophosphate $(A, I)$ \\
\hline
\end{tabular}

$\because: A=$ acaricide $F=$ fungicide $I=$ insecticide 
The latter are rather characterized by utilization of herbicides and fungicides (not included in table 5), according to answers of cattle ranchers living on Ituqui Island (east from the city of Santarém).

EMATER (Empresa de Assistência Técnica e Extensão Rural), which offers technical assistance to small várzea producers, provided a lot of synthetic pyrethroids insecticides (particularly deltamethrin) in the last five years. Besides, some organophosphate insecticides are also used in smaller or equal quantities to the pyrethroids. Finally, copper oxychloride based fungicides are distributed as well by EMATER.

Santarém also includes a large commercial rice field located on floodplains between the Lago Grande de Monte Alegre and the Amazon river, northeast of the urban center. Because of its large area, spraying operations on rice field are carried out by airplane. Table 6 lists products (clearly dominated by various herbi- cides) that were found in the company warehouse on the outskirts of Santarém.

\section{d) Results of the quantitative part of the investigation}

The qualitative part of the investigation clearly showed that organophosphate insecticides occupy a dominant place in the pesticide market with regard to the number of products available. Hence, special attention has been paid to this family of pesticides in order to estimate their quantities used in the county of Santarem. Table 7 provides estimated amounts of four organophosphate insecticides used in agriculture (chlorpyrifos, malathion, metamidophos, methyl-parathion). Presented values include the agricultural utilization either on dry land or on floodplains. Together, the consumption of these four insecticides is estimated for ca. $1910 \mathrm{~kg}$ per year. This value may be considered as an eloquent index of the total consump-

Table 6. Pesticides found in the warehouse of the rice company located on the outskirts of Santarém, State of Pará, Brazil.

\begin{tabular}{|c|c|c|c|}
\hline commercial name & active ingredients (common names) & CAS number & chemical class* \\
\hline Ally ( & methyl-metsulfuron & $74223-64-6$ & sulfonylurea $(\mathrm{H})$ \\
\hline Arrozan® & $\begin{array}{l}\text { molinate } \\
\text { propanil }\end{array}$ & $\begin{array}{l}2212-67-1 \\
709-98-8\end{array}$ & $\begin{array}{l}\text { thiocarbamate }(H) \\
\text { amide }(H)\end{array}$ \\
\hline Fusiflex@ & $\begin{array}{l}\text { fluazifop-p-butyl } \\
\text { fomesafen }\end{array}$ & $\begin{array}{l}79241-46-6 \\
72178-02-0\end{array}$ & $\begin{array}{l}\text { diphenylether }(\mathrm{H}) \\
\text { diphenylether }(\mathrm{H})\end{array}$ \\
\hline Gramoxone '200® & paraquat dichloride & $1910-42-5$ & bipyridinium $(H)$ \\
\hline Karate $50 \mathrm{CE} \odot$ & I-cyhalothrin & $91465-08-6$ & synthetic pyrethroid (1) \\
\hline Reglone $\circledast$ & diquat & $231-36-7$ & bipyridinium $(\mathrm{H})$ \\
\hline$?$ & 2, 4-D† & $72-43-5$ & chlorophenoxy $(\mathrm{H})$ \\
\hline
\end{tabular}

* $\mathrm{F}=$ fungicide $\mathrm{H}=$ herbicide $\mathrm{I}=$ insecticide

$\dagger$ : This product was not found in the warehouse but on the rice field near Lago Grande de Monte Alegre. 
tion of organophosphate insecticides on the territory of Santarém since these four products represent the major part of all the organophosphates used in the study zone.

\section{DISCUSSION}

Among all activities in which pesticides are likely to be used, agriculture uses the greatest array of substances. Considering the amount of products available, the market is dominated by organophosphate insecticides, fungicides, synthetic pyrethroid insecticides, and herbicides. Though it is possible to find substances of other chemical natures (such as carbamates), these are less abundant.

Although Brazil already used organochlorine pesticides in the past, they have almost completely disappeared from its current pesticide array. DDT, its analogs, and HCH's (hexachlorohexanes) are prohibited for agricultural usages in Brazil since 1985 (Caldas et al., 1999), while certain cyclodienes were still used in 1988 (Voldner \& Li, 1995). For sanitary purposes, DDT is not used anymore since 1996 in the case of FNS.
Today, organochlorines are replaced, at least in the studied zone, by less persistent pesticides, such as organophosphates and synthetic pyrethroids. During the investigation, only two products containing the organochlorine insecticide endosulfan (Termicidol ${ }^{\circledR}$ and Thiodan $\mathrm{CE}^{\circledR}$ ) were found in agricultural stores. According to salesmen and sale registers, these products are not used very much.

Amounts of chlorpyrifos, malathion, metamidophos, and methylparathion supplied in table 7 give a rough estimate of quantities of the principal insecticides used in agriculture. Nevertheless, it is necessary to note that these values may be lower than the quantities normally used locally. Indeed, the quantitative part of this study includes data drawn from a less rainy period than the seasonal average, according to hydrograms of the Tapajós river. Because of the leaching of soil and plant surfaces it causes, rain constitutes an important factor positively influencing the pulverization frequency, and thus, quantities of pesticides used.

Organophosphate insecticide consumption in the county of

Table 7. Estimation of annual quantities of some pesticides used in agriculture in the county of Santarém, State of Pará, Brazil.

\begin{tabular}{lllll}
\hline & chlorpyrifos & malathion & metamidophos & methyl-parathion \\
\hline annual use $(\mathrm{kg} / \mathrm{y})^{*}$ & 87,8 & 179,3 & 831,6 & 810,0 \\
by total area of Santarém $\left(\mathrm{kg} / \mathrm{km}^{2} / \mathrm{y}\right)^{*}$ & 0,004 & 0,007 & 0,034 & 0,033 \\
by total agricultural area $\left(\mathrm{kg} / \mathrm{km}^{2} / \mathrm{y}\right)^{*}$ & 0,048 & 0,097 & 0,450 & 0,439 \\
by agricultural area under use $\left(\mathrm{kg} / \mathrm{km}^{2} / \mathrm{y}\right)^{*}$ & 0,083 & 0,170 & 0,788 & 0,768 \\
per capita $(\mathrm{g} /$ inhabitant/y) & 0,363 & 0,740 & 3,434 & 3,345 \\
\hline
\end{tabular}

* = Quantities of active ingredients. 
Santarém is estimated at $8 \mathrm{~g} \cdot$ inhabitant ${ }^{1}$.year ${ }^{-1}$ (considering a total population of 242165 ) and at $1,8 \mathrm{~kg} \cdot \mathrm{km}^{-2}$.year ${ }^{-1}$ (considering an agricultural area under use of $1055 \mathrm{~km}^{2}$ ). With respect to 1995 Brazilian data (IBGE, 1997a), these figures represent $22,7 \%$ of the consumption «per capita» $\left(35 \mathrm{~g} \cdot\right.$ inhabitant $^{-1}$ year ${ }^{1}$ for Brazil) and $81,6 \%$ of the consumption «per agricultural area under use» $\left(2,205 \mathrm{~kg} \cdot \mathrm{km}^{-2}\right.$.year ${ }^{-1}$ for Brazil). Differences between figures for Santarém and Brazil may be due to many factors. First, the relative poverty of Santarém (income below the Brazilian average) suggests that this county uses less pesticides than the national average. Another factor, arising from the methodology, is that this study only considered amounts of the four main organophosphate insecticides, regardless of other organophosphates seldom used.

\section{CONCLUSION}

The use of organophosphate insecticides in agriculture, particularly on várzeas, implies some risks which need to be assessed in a more exhaustive local study on contamination. On one hand, insecticides used are low $\mathrm{LD}_{50}$ compounds (Gallo \& Lawryk, 1991), therefore they are often very toxic. Some of them, methyl-parathion and metamidophos under specific formulations, have been put under restricted use by the USEPA (United States Environmental Protection Agency) because of their toxicity or long persistence in the environment (Bohmont, 1990). On the other hand, várzeas represent an important and sensitive part of the Amazonian ecosystem because they constitute a boundary between terrestrial and aquatic environments (de Mérona, 1993). They shelter a huge array of organisms, which belong to both biomes, that are often in close interaction (Wiens et al., 1985). The usage of pesticides in this environment may harm some sensitive species, consequently affecting the trophic flux or ecological processes.

Although they are not as persistent and as bioaccumulable as organochlorines (Ecobichon, 1991), organophosphates can be accumulated by some organisms. Such is the case in certain mollusks (Serrano et al. 1995; Dauberschmidt et al., 1996), amphibians (Hall \& Kolbe, 1980), and even fish (Takase \& Oyama, 1985; Sabharwal \& Belsare, 1986), which may then represent a hazard for superior trophic levels. This may be of special concern in the Brazilian Amazon as fish constitute the principal source of animal proteins for local human populations (Saint-Paul \& Bayley, 1979; Isaac et al., 1996).

Other reasons further reinforce the need for a study on the contamination of the Amazonian environment by pesticides. Firstly, most studies on pesticide fate have been carried out in temperate climates. Since it appears that the environmental behavior of pesticides is greatly influenced by climatic conditions (Wania \& MacKay, 1995), significant differences may occur between data coming from temperate regions and those observed in tropics. Secondly, there is a great variabil- 
ity of toxic effects from one species to another and from one organophosphate to another (Wallace, 1992; Sánchez-Fortún et al., 1995; Serrano et al. 1995) and only a few studies have dealt with Amazonian fish and organophosphate intoxication. Finally, many projects aiming to increase the agricultural exploitation of várzeas of the Lower-Amazon are being considered. However, the possible impact of a greater pesticide consumption on floodplains does not appear to be of great concern.

\section{ACKNOWLEDGEMENTS}

Authors want to thank the Canadian NSERC and the International Cooperation Office of UQAM for their financial support. A special thanks to Tatiana Brasil Brandão Gandra from COMDEC of Santarém and to Dr. Gladys Beatriz Martinez, of EMBRAPA, for their precious collaboration. Thanks to Aldo Gomes Queiroz, coordinator of the UFPa campus of Santarem, and to students of the Laboratório de Biologia Ambiental. Thanks finally to Dalie Giroux, Martin Kainz, and Charles Henri Warren for their advice and help in the translation of this paper.

\section{Literature cited}

Baktharatchagan, R.; David, B.B. 1991. Evaluation of Trebon (ethofenprox) for insecticidal efficacy against mosquito larvae and on nontarget organisms. Indian Journal of Malariology, 28(4):249-253.

Bohmont, B.L. 1990. The standard pesticide user's guide. Prentice Hall, Inc., Toronto. $498 \mathrm{p}$.
Caldas, E.D.; Coelho, R.; Souza, L.C.K.R.; Silva, S.C. 1999. Organochlorine pesticides in water, sediment, and fish of Paranoá Lake of Brasília, Brazil. Bulletin of Environmental Contamination and Toxicology, 62:199-206.

Dauberschmidt, C.; Dietrich, D.R.; Schlatter, C. 1996. Toxicity of organophosphorus insecticides in the zebra mussel, Dreissena polymorpha P. Archives of Environmental Contamination and Toxicology, 30(3):373-378.

de Mérona, B. 1993. Conditions écologiques de la production dans une île de plaine inondèe d'Amazonie Centrale, un projet multidisciplinaire. Amazoniana, 12(34):353-363.

Brasil. 1998. Legislação federal de agrotóxicos e afins. Ministério da Agricultura, Brasilia.

Diraviam, J.; Viraktamath, C.A. 1993. Toxicity of some insecticides to Curinus coeruleus Mulsant (Coleoptera: Coccinellidae), an introduced predator of the subabul psyllid. Entomon, 18(1-2):77-79.

Ecobichon, D.J. 1991. Toxic effects of pesticides. In: Amdur, M.O.; Doull, J.; Klaassen, C.D. (Eds). Casarett and Doull's toxicology. The basic science of poisons. $4^{\text {th }}$ edition. Mc Graw-Hill, Montréal. pp. 565-622.

Etchart, G. 1997. Sustainable resource management in the Brazilian Amazon : the case of community of Tiningú. Coastal Management, 25:205-226.

Fearnside, P.M. 1987. Deforestation and international economic development projects in Brazilian Amazonia. Conservation Biology, 1(3):214-221.

Fearnside, P.M. 1990. Predominent land uses in Brazilian Amazonia. In: Anderson, A.B. (Ed). Alternatives to deforestation: steps toward sustainable use of the Amazon Rain Forest. Columbia University Press, New York. pp. 233-251.

Furch, K. 1997. Chemistry of várzea and igapó soils and nutrient inventory of their floodplain forests, In: Junk, W.J. (Ed). The Central Amazon Floodplain. Ecological 
Studies. Volume 126. Springer-Verlag, Berlin. pp. 47-67.

Gallo, M.A.; Lawryk, N.J. 1991. Organic phosphorus pesticides. In: Hayes Jr, W.J.; Laws Jr, E.R. (Eds). Handbook of pesticide toxicology. Volume 2. Classes of pesticides. Academic Press, Inc., Toronto, pp. 917-1123.

Hall, A.L, 1989. Developing Amazonia. Deforestation and social conflict in Brasil's Carajás programme. Manchester University Press, New York. 295p.

Hall, R.J.; Kolbe, E. 1980. Bioconcentration of organophosphorus pesticides to hazardous levels by amphibians. Journal of Toxicology and Environmental Health, 6:853-860.

IBGE. 1997a. Censo agropecuário 1995-96. Instituto Brasileiro de Geografia e Estatistíca (IBGE), Brasilia.

IBGE. 1997b. Contagem da população 1996. Volume 1. Instituto Brasileiro de Geografia e Estatistica (IBGE), Brasilia.

Isaac, V.J.; Milstein, A.; Ruffino, M.L. 1996. A pesca artesanal no Baixo Amazonas: análise multivariada da captura por espécie. Acta Amazonica, 26(3):185-208.

Jena, M.; Dani, R.C.; Rajamani, S. 1992. Effectiveness of insecticides against the rice leaf folder, Cnaphalocrocis medialis Guenee. Indian Journal of Plant Protection, 20(1):43-46.

Krishnaiah, N.V.; Kalode, M.B. 1993. Efficacy of ethofenprox against leafhoppers and planthoppers, with emphasis on preventing resurgence of brown planthopper. Crop Protection, 12(7):532-538.

McGrath, D.G.; De Castro, F.; Futemma, C.; De Amaral, B.D.; Calabria, J. 1993. Fisheries and the evolution of resource management on the Lower Amazon floodplain. Human Ecology, 21(2):167-195.

Ray, D.E. 1991. Pesticides derived from plants and other organisms. In: Hayes Jr, W.J.; Laws Jr, E.R. (Eds). Handbook of pesticide toxicology. Volume 2. Classes of pesticides. Academic Press, Inc., Toronto. pp. 585-636.

Sabharwal, A.K.; Belsare, D.K. 1986. Persistence of methyl parathion in a carp rearing pound. Bulletin of Environmental Contamination and Toxicology, 37:705-709.

Saint-Paul, U.; Bayley, P.B. 1979. A situação da pesca na Amazônia central. Acta Amazonica, 9(4):109-144.

Sánchez-Fortún, S.; Sanz-Barrera, F.; Barahona-Gomariz, M.V. 1995. Acute toxicity of selected insecticides to the aquatic arthropod Artemia salina. Bulletin of Environmental Contamination and Toxicology, 54:76-82.

Scatena, F.N.; Walker, R.T.; Homma, A.K.O.; De Conto, A.J.; Ferreira, C.A.P.; Carvalho, R.A.; Neves da Rocha, A.C.P.; Don Santos, A.I.M.; De Oliveira, P.M. 1996. Cropping and fallowing sequences of small farms in the "terra firme» landscape of the Brazilian Amazon; a case study from Santarém, Pará. Ecological Economics, 18:29-40.

SEMAB. 1997. Plano municipal de agropecuária. Periodo 1997/2000. Prefeitura Municipal de Santarém. Núcleo de Planejamento da Secretaria Municipal de Agricultura e Abastecimento (SEMAB), Santarem.

Serrano, R.; Hernández, F.; Peña, J.B.; Dosda, V.; Canales, J. 1995. Toxicity and bioconcentration of selected organophosphoruś pesticides in Mytilus galloprovincialis and Venus gallina. Archives of Environmental Contamination and Toxicology, 29:284-290.

Shakoori, A.R.; Ilyas, M.; Aziz, F. 1992. Toxicity of sublethal doses of Trebon (ethofenprox) on total blood serum proteins, acetylcholinesterase activity and SDS-PAGE pattern of blood serum proteins of Cirrhinus mrigala. Pakistant Journal of Zoology, 24(3):235-241.

Takase, I.; Oyama, H, 1985. Uptake and bioconcentration of disulfoton and its oxidation compounds in carp, Cyprinus carpio L. Journal of Pesticide Science, 10(1):47-53.

Voldner, E.C.; Li, Y.F. 1995. Global usage of selected persistent organochlorines. The Science of the Total Environment, 160/ 161:201-210. 
Wallace, K.B. 1992. Species-selective toxicity of organophosphorus insecticides : a pharmacodynamic phenomenon. In: Chambers, J.E; Levi, P.E. (Eds). Organophosphates. Chemistry, fate, and effects. Academic Press, Toronto. pp. 79-105.

Wania, F.; Mackay, D. 1995. A global distribution model for persistent organic chemicals. The Science of the Total Environment, 160/161:211-232.

Wiens, J.A.; Crawford, C.S,; Gosz, J.R. 1985. Boundary dynamics : a conceptual framework for studying landscape ecosystems. Oikos, 45:421-427. 